\title{
Evaluation of Water Quality of the Nile River at Damietta branch as affected by Omer Bek drain
}

\author{
M.M. Bahgat ${ }^{1}$, W. I.A. Saber ${ }^{2}$ and M.R. Zaki ${ }^{3 *}$ \\ ${ }^{1}$ College of Pharmacy, Jazan University, Saudi Arabia. \\ ${ }^{2}$ Microbial Activity Unit, Microbiology Department, Soils, Water and Environment Research Institute, Agricultural \\ Research Center (ID: 60019332), Giza (P.N. 12619), Egypt. \\ ${ }^{3}$ Botany Department, Faculty of Science, Port Said University, Port Said, Egypt.
}

Received: 8 November 2017 /Accepted: 9 January 2018

*Corresponding author: alfad2004@gmail.com

\begin{abstract}
Over two-year period starting June 2014, 72 water samples were collected from Omar Bek drain, Damietta branch upstream and downstream. Based on physical, chemical and bacteriological results obtained, The physical analysis was temperature, $\mathrm{pH}$, and turbidity, chemical analysis was total dissolved salts (TDS), electrical conductivity(EC), alkalinity, total hardness, manganese, iron, nitrite (NO2), nitrate (NO3), ammonia (NH3), dissolved oxygen (DO), and bacteriological analyses involved total coliforms (TC), fecal coliforms (FC), and Fecal Streptococci (FS). Results showed Omar Bek drain water carries high concentrations of pollutants which affected on all parameter of Nile River downstream. Also, the present investigation showed that Damietta branch upstream was a good raw water quality while Damietta branch downstream was affected by presence of Omer Bek drain.
\end{abstract}

Keywords: Omer Bek drain; Nile River; Water Quality; Bacteriological analysis; Damietta branch.

\section{Introduction}

Water is the source of the life. Life started from water and it goes on even now since water is omnipresent. Man gets frantic at the very thought of the scarcity of water and he think of crossing the outer space in search of this universal sustainer of life.

The main source of water in Egypt is the Nile River. Egypt is unique among other countries in its dependence on water from one deterministic source. The Nile water agreement with Sudan, allocates 55.5 Billion Cubic Meters/year to Egypt.
This amount is guaranteed by the multi-year regulatory capacity provided by the High Aswan Dam. Abdin and Gaafar (2009). Omar Bek drain is considered one of the main and longest drains in El-Gharbia governorate that discharges its wastes directly into Damietta branch, which represents the main source of water pollution along the Damietta branch of the Nile River (Fig. 1 a, b and c), receives about $600,000 \mathrm{~m}^{3}(158,503,200$ gallons) daily of untreated domestic, agricultural, and industrial waste. Mostafa and Peters (2016).This drain affected on the Nile River water quality which can used by many water treatment 
plants (Meet Khamis, Talkha, East Mansoura treatment plant, and many of compact water treatment plant) which affected on the product water and coast product. Ezzat and Reham (2012). Diseases which caused by pathogenic microorganisms that most commonly are transmitted in contaminated fresh water called waterborne. Rosario et. al., (2009). Infection commonly results during bathing, washing, drinking, in the preparation of food, or the consumption of food that is infected; several pathogenic organisms in contaminated water are the basic causes of gastrointestinal illnesses in human. WHO (2011). Some of the pathogens are known to cause several outbreaks of diseases by releasing toxins in the human body. Microorganisms causing diseases that characteristically are waterborne include protozoa, bacteria, and viruses. APHA (2012).

The major water related diseases caused by bacteria are cholera, salmonellosis and shigellosis. The majority of bacterial pathogens in wastewater are found in the gastrointestinal tract of humans and animals. They mostly belong to the following genera: Vibrio, Salmonella, Shigella, and E. coli. (Adingra 2012).

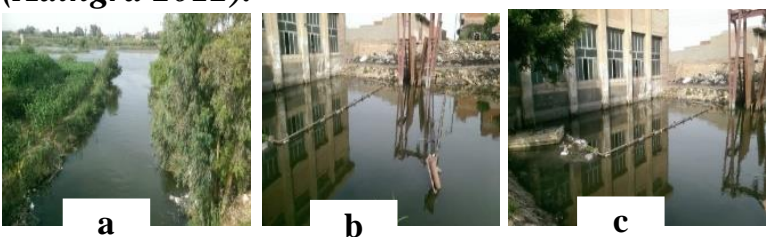

Fig.1. Omer Bek drain

This study aims to study the effect of Omer Bek drain on the Nile River at Damietta branch and evaluates its suitability for reuse by Meet Khamis water treatment plant to make drinking water.

\section{Material and methods}

\section{Study Area}

The study area is located at the eastern branch of the Nile River (Damietta branch). The study area receives a considerable pollution load from a variety of industrial, domestic, and agricultural effluents from Omer Bek drain. Samples of water were taken monthly from the Nile River upstream $500 \mathrm{~m}$ before Omer Bek drain, from Omer Bek drain and from the Nile River after $500 \mathrm{~m}$ downstream of Omer Bek drain. The geographical location of this study area $\left(30^{\circ} 56^{\prime} 13.8^{\prime \prime} \mathrm{N}\right.$ $31^{\circ} 15^{\prime} 01.7^{\prime \prime E}$ ) is shown in Fig. 2. Water samples monthly collected for a full tow annual cycle between June 2014 and May 2016. Water samples were subjected for various physical, chemical analyses (Inorganic, Organic) and bacteriology analysis.

Sampling procedures as well as analytical methods for both chemical and bacteriological determinations were carried out according to methods described in APHA [2012]. The samples placed in a lightproof insulated box containing ice-packs to ensure rapid cooling and preservation temperature, attempt to keep samples at $8^{\circ} \mathrm{C}$ during transport to the laboratory.

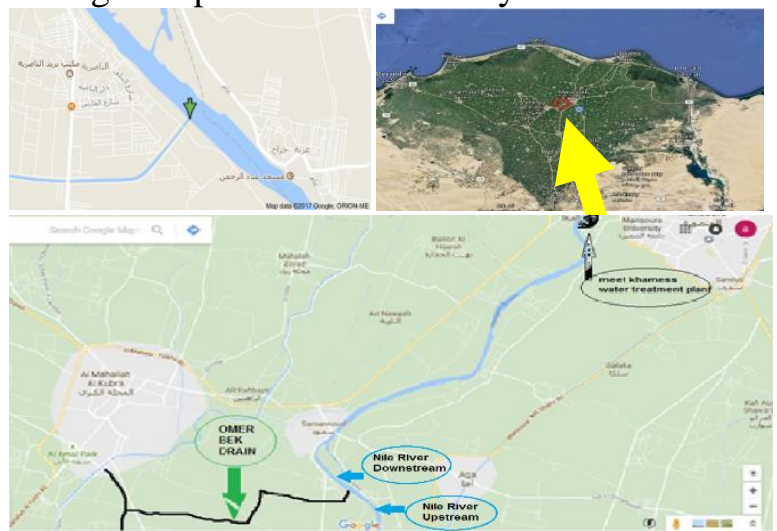

Fig. 2. Study area at Omer Bek drain and Meet Khamis water treatment plant

\section{Chemical Analysis:}

Field observation including Water temperature, $\mathrm{pH}$ by a Jenway dual temperature and $\mathrm{pH}$ meter model 370 , turbidity hack portable model 2100 n, Total dissolved salts (TDS), Electrical Conductivity (EC) using Martini Mi 170 bench were included. In lab Inorganic chemical parameters including Alkalinity, Total hardness, Manganese, Iron, Nitrite $\left(\mathrm{NO}_{2}\right)$, Nitrate $\left(\mathrm{NO}_{3}\right)$, Ammonia $\left(\mathrm{NH}_{3}\right), \quad$ Dissolved Oxygen (DO)according to APHA [8], Organic chemical parameters TOC by Severes 3510C (USA), Polycyclic Aromatic Hydrocarbons (PAHs) by High Performance Liquid Chromatography (HPLC) Dionex Ultimate 3000 (USA), Carbamates ) by High Performance Liquid Chromatography (HPLC) Dionex Ultimate 3000 (USA) which is detected by a fluorescence detector, organochlorine pesticides by Gas Chromatography(GC) Varian CP 3800-Saturan 2200-GC MS/MS, Australian were included.

\section{Bacteriological Analysis:}

The bacteriological Analysis was determined according to methods described in APHA [8]. All 
collected samples were examined within analysis not exceed $8 \mathrm{~h}$, and $30 \mathrm{~h}$ is considered the absolute maximum time after collection. For counting total bacterial count by pour plate method on $\mathrm{R} 2 \mathrm{~A}$ media, bacterial count was computed by the following equation:

MPN/100 ml $=$ colonies counted $\div$ actual volume of sample placed, $\mathrm{ml} \times 100$

Total coliforms on lauryl sulfate and confirmed on brilliant green media, fecal coliforms on A1 media and fecal streptococci on azid dextrose media by Multiple-Tube Fermentation Technique, Computed by the following equation.

$\mathrm{MPN} / 100 \mathrm{~mL}=($ Table MPN $/ 100 \mathrm{~mL}) \times 10 / \mathrm{V}$

$\mathrm{V}=$ volume of sample portion at the lowest selected dilution (APHA 2012).

\section{Results and discussion:}

\section{Physical and inorganic chemical properties}

Physicochemical parameters results were illustrated in table (1) showed that temperature plays an important role in the chemical and physiological behavior of biotic components of aquatic ecosystem, and is one of the most important physical factors that influence species distribution on earth [8]. The temperature for all sampling locations ranged between $16.0-31.7^{\circ} \mathrm{C}$ with mean value $22.9-23.1^{\circ} \mathrm{C}$ governed by seasonal variations and thus indicating no thermal pollution. The $\mathrm{pH}$ values ranged between 7.057.77 in Nile River upstream, while it ranged between 6.63-7.33 in Omer Bek, and ranged between 6.93- 7.75 in Nile river downstream showing slight decrease downstream which may be attributed to high organic matter from Omar Bek drain. In all cases $\mathrm{pH}$ values were within permissible limits (6.5- 8.5) (Toufeek and Korium, 2009).

Turbidity in the Nile River upstream ranged between 2.7-7.4 NTU (Nephelometric Turbidity Unit) and was ranged between 7.6-26.7 NTU in Omer Bek drain. The highest turbidity duo to the high level of clay, silt, organic matter and microorganisms, which affected on the Nile River downstream that ranged between 5.1-12.1 NTU. Abdo (2010); Salem, Sayed and Damarany (2014).

Total dissolved solids (TDS) concentrations in Nile River upstream ranged from 197-345 mg/l and ranged between 525-1341 mg/l in Omer Bek, and has increased in the Nile river downstream where it ranged between $279-418 \mathrm{mg} / \mathrm{l}$ which may be attributed to inorganic salts dissolved in water originating from sewage, and EC ranged between $324-573 \mu \mathrm{S} / \mathrm{cm}$ in the Nile river upstream and the highest value recorded in Omer Bek drain 2240 $\mu \mathrm{S} / \mathrm{cm}$ which affected on the Nile river downstream and reached to 421-662 $\mu \mathrm{S} / \mathrm{cm}$. Salem, Sayed and Damarany (2014); Adejuwon and Adelakun (2012).

Alkalinity concentrations ranged between 129$181 \mathrm{mg} / \mathrm{l}$ in Nile river upstream and 319-548 mg/l in Omer Bek drain which affected on the Nile river downstream to become between 157-197 mg/l. Ezzat and Reham (2012); Abdo (2010); Salem, Sayed and Damarany (2014).

Total hardness was fluctuated between 112$195 \mathrm{mg} / \mathrm{l}$ in the Nile river upstream and ranged between 145-228 mg/l in Omer Bek drain and this may be due to the dissolved contents of carbonates and sulfates of calcium and magnesium; at times to a lesser degree presence of chlorides, nitrates and sometimes iron and aluminum is effective in causing hardness which affected on the Nile river downstream to a range between 130-216 mg/l (Shaikh and Mandre, 2009).

Iron and manganese is low amount in surface water, where manganese was fluctuated between $0.01-0.07 \mathrm{mg} / \mathrm{l}$ and iron was $0.13-0.29 \mathrm{mg} / \mathrm{l}$ in Nile river upstream, while the higher iron and manganese was recorded in Omer Bek drain (manganese $0.2-0.6 \mathrm{mg} / \mathrm{l}$, iron $0.26-0.42 \mathrm{mg} / \mathrm{l}$ ) as a result of the high amount of pollution of this drain, which affected on the Nile River downstream and increased more in the Nile river upstream. Trivedi et al., (2010).

Ammonia concentrations ranged between 0.19-0.6 $\mathrm{mg} / \mathrm{l}$ in Nile River upstream, $0.54-2.24 \mathrm{mg} / \mathrm{l}$ in Omer Bek drain and $0.26-1.21 \mathrm{mg} / \mathrm{l}$ in Nile River downstream. Ammonia is an indicator of pollution, where it is originating from several pollution sources as agricultural, industrial pollution, sewage waste, and dead animal released in surface water. So, Omer Bek drain have the largest value of ammonia, then Nile River downstream. Abdo (2010); Salem, Sayed and Damarany (2014); El Shakour and Mostafa (2012).

Nitrite $\mathrm{NO}_{2}$ is a transitional, and less stable product in nitrogen cycle and ranged between $0.02-0.08 \mathrm{mg} / \mathrm{l}$ in Nile river upstream, 0.09$0.25 \mathrm{mg} / \mathrm{l}$ in Omer Bek drain and $0.04-0.12 \mathrm{mg} / \mathrm{l}$ in Nile river downstream, where it produced may be due to chemical and biochemical factors where it is oxidized to nitrate or undergo reduction to ammonia in fairly short time, so there is a lower 
rate of the ammonia and nitrates in the water (Foglar 2013).

Nitrate $\mathrm{NO}_{3}$ is fluctuated between $1.62-3.53 \mathrm{mg} / \mathrm{l}$ in Nile River upstream, 5.53-9.32 mg/l in Omer Table 1: Min, Max, and Mean physical, Inorganic, water parameters determined at Nile River Upstream, Omer Bek Drain and Nile River Upstream 2014/2016

\begin{tabular}{|c|c|c|c|c|c|c|c|c|c|c|c|c|c|}
\hline \multirow[b]{2}{*}{ Parameter } & \multirow[b]{2}{*}{ UNIT } & \multicolumn{3}{|c|}{ Nile River Upstream } & \multirow[b]{2}{*}{ S. Error } & \multicolumn{3}{|c|}{ Omer Bek Drain } & \multirow[b]{2}{*}{ S. Error } & \multicolumn{3}{|c|}{ Nile River Downstream } & \multirow[b]{2}{*}{ S. Error } \\
\hline & & MIN & MAX & MEAN & & MIN & MAX & MEAN & & MIN & $\overline{\text { MAX }}$ & MEAN & \\
\hline Temperature & ${ }^{\circ} \mathrm{C}$ & 16.0 & 31.5 & 23.0 & \pm 0.046 & 16.0 & 31.3 & 22.9 & \pm 0.037 & 16.1 & 31.7 & 23.1 & \pm 0.043 \\
\hline $\mathrm{pH}$ & Unit & 7.05 & 7.77 & 7.48 & \pm 0.010 & 6.63 & 7.33 & 6.93 & \pm 0.012 & 6.93 & 7.75 & 7.29 & \pm 0.010 \\
\hline Turbidity & NTU & 2.7 & 7.4 & 4.9 & \pm 0.034 & 7.6 & 26.7 & 15.4 & \pm 0.075 & 5.1 & 12.1 & 7.9 & \pm 0.065 \\
\hline $\begin{array}{l}\text { Total Dissolved } \\
\text { Solids (TDS) }\end{array}$ & $\mathrm{mg} / \mathrm{L}$ & 197 & 345 & 255 & \pm 0.9 & 525 & 1341 & 799 & \pm 1.6 & 279 & 418 & 322 & \pm 2.0 \\
\hline $\begin{array}{c}\text { Electrical } \\
\text { Conductivity (EC) }\end{array}$ & $\mu \mathrm{S} / \mathrm{cm}$ & 324 & 573 & 429 & \pm 1.0 & 886 & 2240 & 1351 & \pm 1.4 & 421 & 662 & 525 & \pm 1.0 \\
\hline Alkalinity & $\mathrm{mg} / \mathrm{L}$ & 129 & 181 & 152 & \pm 0.8 & 319 & 548 & 388 & \pm 2.7 & 157 & 197 & 174 & \pm 0.1 \\
\hline Total Hardness & $\mathrm{mg} / \mathrm{L}$ & 112 & 195 & 145 & \pm 0.9 & 228 & 459 & 311 & \pm 1.2 & 130 & 216 & 163 & \pm 0.8 \\
\hline Manganese & $\mathrm{mg} / \mathrm{L}$ & 0.01 & 0.07 & 0.03 & \pm 0.0014 & 0.20 & 0.62 & 0.34 & \pm 0.0005 & 0.02 & 0.08 & 0.05 & \pm 0.0007 \\
\hline Iron & $\mathrm{mg} / \mathrm{L}$ & 0.13 & 0.29 & 0.20 & \pm 0.0006 & 0.26 & 0.42 & 0.34 & \pm 0.0005 & 0.18 & 0.32 & 0.25 & \pm 0.0005 \\
\hline Nitrite $\left(\mathrm{NO}_{2}\right)$ & $\mathrm{mg} / \mathrm{L}$ & 0.02 & 0.08 & 0.04 & \pm 0.0005 & 0.09 & 0.25 & 0.13 & \pm 0.0009 & 0.04 & 0.12 & 0.08 & \pm 0.0009 \\
\hline Nitrate $\left(\mathrm{NO}_{3}\right)$ & $\mathrm{mg} / \mathrm{L}$ & 1.62 & 3.53 & 2.54 & \pm 0.022 & 5.53 & 9.32 & 7.17 & \pm 0.007 & 3.34 & 5.96 & 4.34 & \pm 0.010 \\
\hline Ammonia $\left(\mathrm{NH}_{3}\right)$ & $\mathrm{mg} / \mathrm{L}$ & 0.19 & 0.60 & 0.32 & \pm 0.0056 & 0.54 & 2.24 & 1.19 & \pm 0.0063 & 0.26 & 1.21 & 0.61 & \pm 0.0059 \\
\hline$\overline{\text { DO }}$ & $\mathrm{mg} / \mathrm{L}$ & 5.45 & 7.44 & 6.47 & \pm 0.026 & 1.54 & 2.62 & 1.94 & \pm 0.006 & 2.17 & 3.46 & 2.81 & \pm 0.008 \\
\hline
\end{tabular}

inorganic and organic wastes as well as from ammonia and nitrate oxidation. High nitrate levels in treated waters will render them hazardous to infants as they induce the "blue baby" syndrome (methemoglobinemia). The maximum amount of nitrite present in Omer Bek drain because of it received high amount of agricultural wastes, human or animal wastes and industrial wastes which affected on the Nile River downstream. Ezzat and Reham (2012); Abdo (2010).

Dissolved oxygen is one of the most important indicator parameter for assessing pollution strength which influences an aquatic ecosystem and basic indicator of ecosystem health. The dissolved oxygen level of Nile river upstream ranged between $1.65-2.62 \mathrm{mg} / \mathrm{l}$ and decreased in Omer Bek drain to a range between 154-2.62 mg/l and this is may be due to the microbiological, and organic wastes which leads to aerobic microorganisms enhanced utilization when decompose organic matter, which affected on Nile river downstream and reached between 2.17-3.46 mg/l. Ezzat and Reham (2012); Vaishali and Punita (2013).

\section{Organic properties of water samples.}

Total organic carbon (TOC) of Nile River upstream changed between 3.37-6.42 mg/l. The highest TOC values were recorded of Omer Bek drain which fluctuated between $11.23-24.72 \mathrm{mg} / \mathrm{l}$ due to received agricultural, domestic, and industrial wastes which affected on the TOC values of the Nile River downstream and extended
Bek drain, and 3.34-5.96 mg/l in Nile River downstream. Nitrate is more stable than other nitrogen compounds in the water and most of them in terms of quantity. It comes from the mer Bek Drain

between 4.09-10.13 mg/l (Fig. 3). Papadakis, et al., (2015).

Carbamate and Organochlorine pesticides $(\mathrm{Cl}$. pesticides) upstream ranged between 0.42-1.12 ppm and 0.01-0.17 ppm, and the maximum Carbamate and Organochlorine pesticides are recorded in Omer Bek drain because of primarily transported from the agricultural fields to surface waters through surface runoff. The amount of applied pesticides lost from the fields and transported to surface waters depends on several factors, including soil physicochemical properties, topography, weather (especially sudden rainfall incidents), agricultural management practices and the chemical properties of each pesticide. The highest pesticides contamination of Omer Bek drain affected on the Nile River downstream carbamate ranged between 0.83-2.44 ppm, and Organochlorine pesticides ranged between 0.040.73 ppm (Fig. 3) Papadakis, et al., (2015).

Some polyaromatic hydrocarbons (PHAs) are known to be toxic to aquatic animals and humans. PAHs higher molecular weight tend to be more stable, persist in the environment longer, are less water soluble, and are more toxic.

The Nile River upstream PHAs ranged between 0.02-0.07 ppm, and Omer Bek drain have the higher amount of PAHs 0.16-0.52 ppm, which may be come from the industrial wastes (Azad et al., (2009), which lead to the increasing of PAHs in the Nile River downstream which ranged between 0.04-0.10 ppm (Fig. 3). 


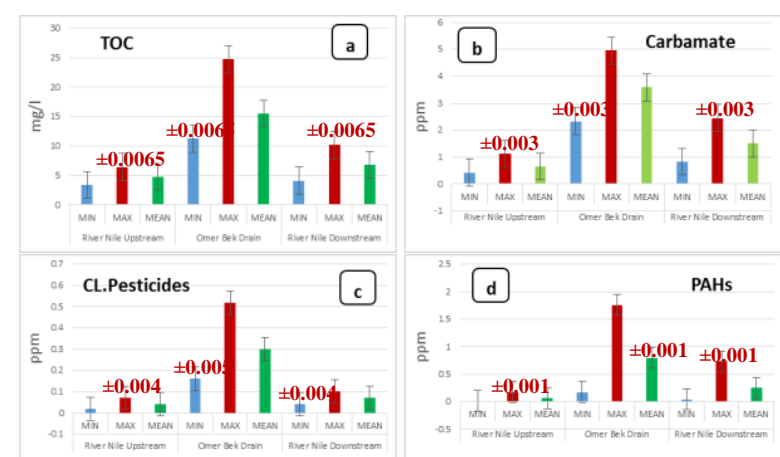

Fig. 3. Min, Max, and Mean Organic properties, determined at Nile River Upstream, Omer Bek Drain and Nile River Upstream 2014/2016 a) Total organic carbon (TOC) (b) Carbamate c) Organochlorine pesticides d) Poly aromatic hydrocarbons (PHAs)

\section{Bacteriological properties of water samples.}

Bacteria are perfect sensors for microbial contamination of surface water because of their fast response to environment. Salem et al., (2014). The use of bacteria as water quality indicators can be watched from two ways. The presence of such bacteria can be taken as an indication of fecal contamination of water and an indication of potential danger of health risks Adejuwon and Adelakun (2012). Total bacterial count measures a range of bacteria that are naturally present in the environment. Total bacterial count (TBC) is a primary standard based on health considerations. Sabae et al., (2006). The minimum total bacterial count recorded on Nile river upstream ranged between $205 \times 10^{4}-152 \times 10^{5} \mathrm{CFU} / 100 \mathrm{ml}$, and high total bacterial count recorded in Omer Bek drain ranged between $425 \times 10^{5}-1551 \times 10^{6} \mathrm{CFU} / 100 \mathrm{ml}$, and this is may be due to the increase of the agricultural activities and the study area receiving the large amounts of sewage which affected on the Nile River water downstream which reached between $425 \times 10^{5}-1551 \times 10^{6} \mathrm{CFU} / 100 \mathrm{ml}$ (Fig. 4). Total Coliform bacteria had been used generally to assess the microbial quality of surface water, and not consider as indicators of faecal contamination, but their presence indicates that water supply may be exposed to contamination by more harmful microorganisms because total coliforms are found ubiquitously in the environment, their presence doesn't always mean evidence of contamination by human feces. It could be an indication of contamination with soil or plant material, which wouldn't indicate any harm to humans. Elala, et al., (2011). Nile river upstream is considered as good surface water quality. Total coliform recorded between 1100$11667 \mathrm{MPN} / 100 \mathrm{~mL} \mathrm{ml}$, and Omer Bek drain is very contaminated water and total coliform ranged between $93.4 \times 10^{4}-175 \times 10^{5} \mathrm{MPN} / 100 \mathrm{~mL}$ and this is may be due to receiving high amount of industrial and agricultural drainage, as well as untreated domestic wastewater which affected on the Nile river downstream and affected on Nile water quality and total coliform ranged between $115 \times 10^{3}-116 \times 10^{4}$ MPN/100 mL (Fig. 4). Jalal and Kumar (2013); Ezzat and Reham (2012).

Faecal coliform bacteria in aquatic environments indicate that the water has been contaminated with the faecal material of man or other animals, and water may have been contaminated by pathogens or disease producing bacteria or viruses, which can also exist in fecal material. The presence of fecal contamination is an indicator that a potential health risk exists for individuals exposed to this water. Faecal coliform fluctuated between 337$2133 \mathrm{MPN} / 100 \mathrm{~mL}$ in Nile river upstream and ranged between minimum of $934 \times 10^{3}$ and a maximum of $175 \times 10^{5} \mathrm{MPN} / 100 \mathrm{~mL}$ on Omer Bek drain and this is may be due to the effluent discharged enriched with organic and domestic sewage which affected on the Nile river water quality downstream giving faecal coliform ranged between $27 \times 10^{3}-227 \times 10^{3}$ MPN/100 mL (Fig. 4) Zaghloul and Elwan (2011); Hamzah et al., (2011).

Faecal Streptococcus normally occurs in faecal matter, where they were used additionally to Fecal Coliform because Fecal streptococci survive well in the environment. Presence of Streptococcus faecalis in the all selected samples confirms faecal contamination. The results showed that low level of faecal Streptococcus on Nile River upstream which fluctuated between maximum 783 MPN/100 mL and minimum $783 \mathrm{MPN} / 100 \mathrm{~mL}$. The high variability in levels and number of faecal streptococcus in Omer Bek drain which reached between $116 \times 10^{3}-937 \times 10^{3} \mathrm{MPN} / 100 \mathrm{~mL}$, and Nile river downstream which ranged between $6.8 \times 10^{3}-79 \times 10^{3}$ (Fig. 4), and this may be due to their presence in a lot of industrial and agricultural wastes and residues of sewage, and human and animal faeces, and variation of environmental conditions. Hamzah et al., (2011); Yehia and Sabae (2011). 


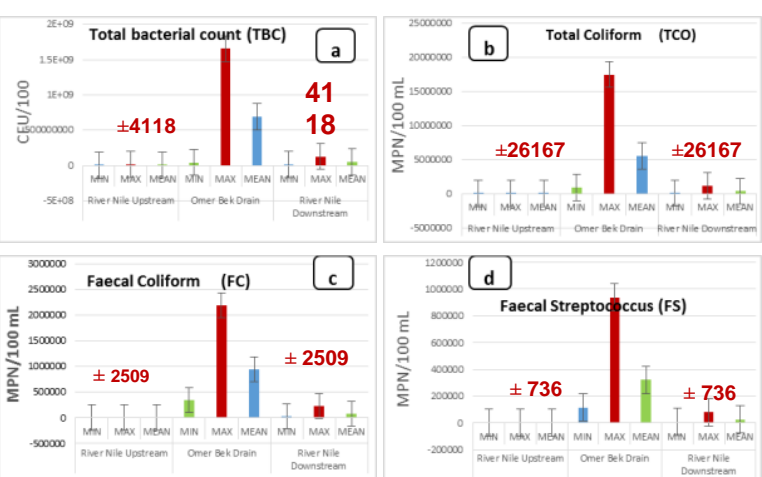

Fig.4. Min Max, and Mean (a) total bacterial count, (b)total coliform, (c) faecal coliform, and (d)faecal streptococcus determined at Nile River Upstream, Omer Bek Drain and Nile River Upstream 2014/2016

\section{Conclusion}

Omar Bek drain, one of the largest sources of pollution affecting the Damietta branch of the Nile water, which carries many of the domestic, agricultural and industrial waste. Authorities should do more efforts to stop Omer Bek drain effluents to improve the quality of Nile river downstream water that can used by many water treatment plants, and provides the economic level also from the use of alum and chlorine

\section{References}

Abdin, A. E., and Gaafar, I. (2009). Rational water use in Egypt. Technological perspectives for rational use of water resources in the Mediterranean region, $88,11-27$.

Mostafa, M. K., and Peters, R. W. (2016). Effect of Changing the Effluent Path of Omar-Bek Drain on the Damietta Branch Water Quality. J. Water Resource Prot, 8(1), 20.

Ezzat, S. M., and Reham, M. E. (2012). Omar Bek Drain Water Quality and Its Impact on Damietta Branch, River Nile-Egypt. Am Eurasian J Agric Environ Sci, 12, 472-483.

Rosario, K., Symonds, E. M., Sinigalliano, C., Stewart, J., \& Breitbart, M. (2009). Pepper mild mottle virus as an indicator of fecal pollution. Appl. Environ. Microbiol., 75(22), 7261-7267.

World Health Organization. (2011). Guidelines for drinking-water quality. $\varepsilon-r)$ r, $r \cdot r$.

American Public Health Association(APHA) (2012): Standard Methods for the Examination of Water and Wastewater, 22th ed, American Public Health Association, Washington, D.C.

Adingra, A. A., Kouadio, A. N., Blé, M. C., and Kouassi, A. M. (2012). Bacteriological analysis of surface water collected from the Grand-Lahou lagoon, Cte divoire. Afr J Microbiol Res,6(13), 3097-3105.

Toufeek, M.A. and M.A. Korium, 2009. Physicochemical characteristics of water quality in Lake Nasser water. Global J. Environ. Res., 3(3): 141148.

Abdo, M. H. (2010). Environmental and water quality evaluation of Damietta branch, River Nile, Egypt. African J. Biol. Sci, 6(2), 143-158.

Salem, W. M., Sayed, W. F., and Damarany, K. A. (2014). Seasonal physico-chemical and microbiological pollutants of potable groundwater in Qena governorate, Egypt: A case study. Afr. J. Environ. Sci. Technol., 8(12), 730-739.

Adejuwon, J. O., and Adelakun M. A. (2012). Physiochemical and bacteriological analysis of surface water in Ewekoro local government area of Ogun state, Nigeria: Case study of Lala, Yobo and Agodo rivers. Int. J. Water Res. Environ. Eng., 4(3), 66-72.

Shaikh, A. M., and Mandre, P. N. (2009). Seasonal study of physico-chemical parameters of drinking water in Khed (Lote) industrial area. Int. Res. J, 2, 169-171.

Trivedi P, Bajpai A, Thareja S (2010). Comparative Study of Seasonal Variation in physico-chemical characteristics in drinking water quality of Kanpur, India with reference to 200 MLD filteration plant and groundwater. Nat. Sci. 8:11-17.

El Shakour, E. H. A., and Mostafa, A. (2012). Water quality assessment of river Nile at Rosetta branch: impact of drains discharge. Middle-East J Sci Res, 12(4), 413-423.

Foglar, L. (2013). Nitrate Removal in aContinuousFlow Stirred Reactor. CHEM BIOCHEM ENG Q, 27(1), 7-13.

Vaishali, P., and Punita, P. (2013). Assessment of seasonal variation in water quality of River Mini, at Sindhrot, Vadodara. International journal of environmental sciences, 3(5), 1424.

Shreadah, M. A., Said, T. O., Younis, A. M., \& Farag, R. S. (2006). Speciation of Organotin Compounds in Sediments of semi-closed areas along the Mediterranean Coast of Alexandria. J. Chem. Ecol., 22(5), 395-404.

Papadakis, E. N., Vryzas, Z., Kotopoulou, A., Kintzikoglou, K., Makris, K. C., \& PapadopoulouMourkidou, E. (2015). A pesticide monitoring survey in rivers and lakes of northern Greece and its human and ecotoxicological risk assessment. Ecotoxicol. Environ. Saf., 116, 1-9.

Azad, L. T., Sari, A. E., and Tavabe, K. R. (2009). Determination of rest-oil pollution (polycyclic aromtic hydrocarbons) in surface water of three international wetlands of Iran. J. Environ. Res. and Develop, Vol, 4(2). 
Sabae, S. Z., Hazaa, M. M., Aballah, S. A., Awny, N., and Dabbor, S. M. (2006). Studies on bacterial indicators of water pollution and bioremediater isolates for $\mathrm{Cu} 2+, \mathrm{Fe} 2+$ and $\mathrm{Zn} 2+$ in Rosetta Brach River Nile, Egypt. Egypt. J. Biotechnol., 22, 77104.

Jalal, F. N., and Kumar, M. S. (2013). Water quality assessment of Pamba River of Kerala, India in relation to pilgrimage season. Int. J. Res. Chem. Environ, 3(1), 341-347.

Zaghloul, S. S., and Elwan, H. (2011). Water quality deterioration of middle Nile Delta due to urbanizations expansion, Egypt. In Fifteen International Water Technology Conference, IWTC-2011, Alexandria, Egypt (pp. 1-17).
Hamzah, A. I. N. O. N., Kipli, S. H., Ismail, S. R., Una, R., and Sarmani, S. (2011). Microbiological study in coastal water of Port Dickson, Malaysia. Sains Malays, 40(2), 93-99.

Yehia, H. M., and Sabae, S. Z. (2011). Microbial pollution of water in El-Salam canal, Egypt. AmerEurasian J Agri \& Environ Sciences, 11, 305-309.

El-Shenawy, M. A. (2005). Staphylococcus aureus and fecal indicators in Egyptian coastal waters of Aqaba Gulf, Suez Gulf, and Red Sea. Egypt J Aquatic Res, 31(2), 113-124.

Elala, D., Labhasetwar, P., and Tyrrel, S. F. (2011). Deterioration in water quality from supply chain to household and appropriate storage in the context of intermittent water supplies. Wat Sci Tech, 11(4), 400-408.

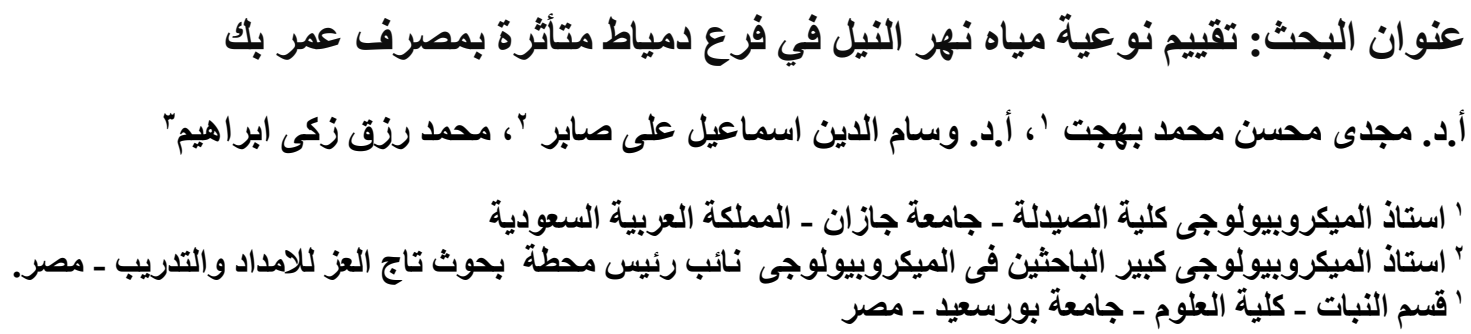

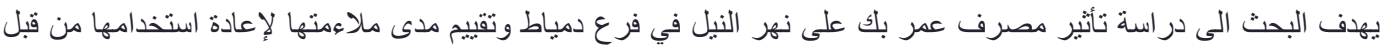

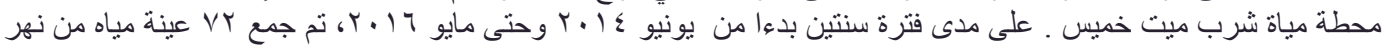

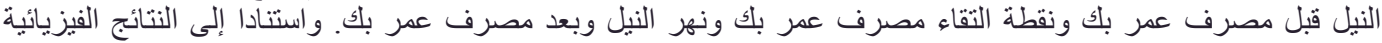

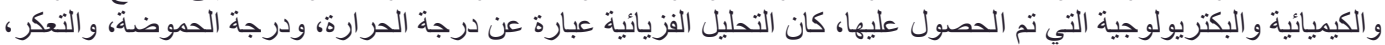

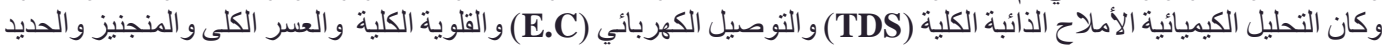

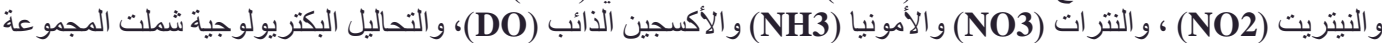

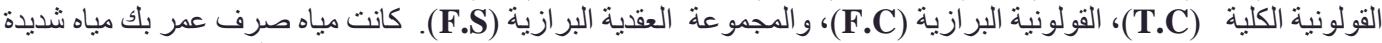

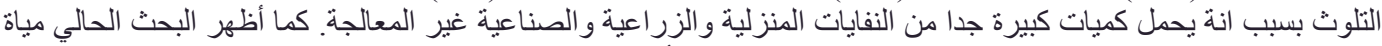

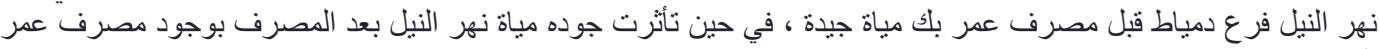

